\title{
TINGKAT TUTUR BAHASA JAWA MAHASISWA PGMI INSURI PONOROGO
}

\author{
Rizki Amalia Sholihah
}

\author{
Institut Agama Islam Sunan Giri Ponorogo \\ J1. Batoro Katong no 32 Ponorogo Jawa tImur \\ Email: rizkiamalias88@gmail.com
}

\begin{abstract}
Javanese is the first language consisting of the people of Ponorogo, East Java. In the first language that was mastered, many of the speakers did not properly and correctly in its use at the speech level. Javanese in the environment of the Madrasah Ibtidaiyah Teacher Education Study Program at the Sunan Giri Ponorogo Islamic Institute which is classified into two levels of speech namely ngoko and krama. This research is a qualitative descriptive study with research subjects being PGMI study program students at Insuri Ponorogo divided into 3 groups. The selection of PGMI study program students as subjects of this research is considered to represent Javanese language courses for 3 semesters. The research data was collected using an instrument containing a questionnaire containing the background of language users and Javanese Ngoko and Krama vocabulary entries. The results of this study prove the Javanese language ability of group 1 (19 respondents) gained the highest score of 88 and the lowest score of 75 was 2 respondents. In group 2, there were 13 respondents with the highest score of 84 and the lowest score was 48 . For group 3 including 19 respondents with the highest score was 92 and the lowest was 80 . The results of language skills in group 1 were the highest score of 40 and the lowest score was 11 , the group 2 with the highest score of 44 and the lowest score of 0 , and group 3 with the highest score of 35 with a score of 0 . From these results it can be recognized if the mastery of Javanese Ngoko level has a better score than the Javanese language Krama can easily be adapted to PGMI Insuri study program students Ponorogo is more knowledgeable in the level of speech in Javanese Ngoko.
\end{abstract}

Keywords:

Javanese, ngoko, krama, speech level, students

\begin{abstract}
Abstrak
Bahasa Jawa merupakan bahasa pertama mayoritas masyarakat Ponorogo, Jawa Timur. Namun sebagai bahasa pertama yang dikuasai, banyak diantara penuturnya yang tidak menguasai dengan baik dan tepat dalam penggunaannya terutama dalam tingkat tuturnya. Penelitian ini bertujuan untuk mengetahui penguasaan tingkat tutur bahasa Jawa di lingkungan mahasiswa program studi Pendidikan Guru Madrasah Ibtidaiyah di Institut Agama Islam Sunan Giri Ponorogo yang diklasifikasikan dalam dua tingkat tutur yaitu ngoko dan krama. Penelitian ini merupakan penelitian deskriptif kualitatif dengan subjek penelitian adalah mahasiswa program studi PGMI di Insuri Ponorogo yang dibagi menjadi 3 kelompok. Dipilihnya mahasiswa prodi PGMI sebagai subjek penelitian ini adalah dikarenakan adanya mata kuliah bahasa Jawa selama 3 semester. Data penelitian ini dikumpulkan dengan menggunakan instrumen berupa kuesioner yang berisi latar belakang pengguna bahasa dan isian kosakata bahasa Jawa Ngoko dan Krama. Hasil penelitian ini menunjukkan kemampuan berbahasa Jawa ngoko dari kelompok 1 (19 responden) memperoleh skor tertinggi 88 dan skor terendah adalah 75 sebanyak 2 responden. Di kelompok 2, terdapat 13 responden dengan skor tertinggi 84 dan skor terendah adalah 48. Untuk kelompok 3 terdapat 19 responden dengan hasil skor tertinggi adalah 92 dan terendah 80. Hasil kemampuan bahasa krama di kelompok 1 yaitu skor tertinggi 40 dan skor terendah adalah 11, kelompok 2 dengan skor tertinggi 44 dan skor terendah 0, dan kelompok 3 dengan skor tertinggi 35 dengan skor 0. Dari hasil tersebut dapat diketahui jika penguasaan tingkat tutur bahasa Jawa ngoko memiliki skor lebih baik daripada bahasa jawa krama sehingga dapat dikatakan bahwa mahasiswa prodi PGMI Insuri Ponorogo lebih menguasai tingkat tutur bahasa Jawa ngoko.
\end{abstract}

Kata kunci:

bahasa Jawa, ngoko, krama, tingkat tutur, mahasiswa

\section{A. PENDAHULUAN}

Dalam masyarakat Jawa terdapat pembagian dialek sosial, atau tingkat tutur (speech levels) atau undha-usuk atau unggah-ungguhing Bahasa Jawa. Tingkat tutur ini merupakan variasi berbahasa yang perbedaannya ditentukan oleh anggapan penutur (O1) dan relasinya terhadap orang yang diajak berbicara (O2). Unggah ungguh bahasa Jawa adalah adat sopan santun, etika, tata susila, dan tata krama berbahasa Jawa, dan hal ini tidak hanya terbatas pada bentuk tuturan tetapi juga menyangkut pada tindak tanduknya. 
Sudaryanto ${ }^{1}$ membagi tingkat tutur bahasa Jawa atas empat tingkatan yakni:
1. Ngoko
2. Ngoko alus
3. Krama
4. Krama alus

Pada prinsipnya tingkat tutur bahasa Jawa ada dua ${ }^{2}$ yaitu ragam ngoko dan ragam krama. Ragam ngoko kemudian dibedakan lagi menjadi dua, yaitu ragam ngoko lugu dan ragam ngoko alus. Ragam ngoko lugu berupa tuturan yang semua leksikonnya berasal dari kelompok ngoko (kosa kata yang netral) tanpa diselipi leksikon yang berasal dari kelompok krama, krama inggil maupun krama andhap.

Untuk ragam ngoko alus berupa tuturan yang leksikonnya berasal dari leksikon ngoko dan disisipi dengan leksikon yang berasal dari leksikon krama, krama inggil ataupun krama andhap. ${ }^{3} \quad$ Pemakaian leksikon krama, krama inggil ataupun krama andhap pada ragam ngoko alus ini berfungsi untuk menghormati mitra tutur. Lalu untuk kosa kata ragam krama lugu berasal dari leksikon krama, madya, dan netral. Munculnya leksikon krama inggil ataupun krama andhap adalah untuk menghormati mitra tutur. Sedang ragam krama alus berkosa kata yang berasal dari leksikon krama ditambah dengan leksikon dari kelompok krama inggil dan krama andhap. Penggunaan ragam ini juga berfungsi untuk menghormati mitra tutur. Adanya berbagai ragam tingkatan Bahasa Jawa merupakan refleksi sosial yang terdapat dalam masyarakat Jawa, yang kerap dihubungkan dengan unggah-ungguh bahasa, salah satunya bisa menggunakan ragam krama atau krama inggil pada orang yang dianggap memiliki status sosial lebih tinggi. Sedang dengan menggunakan ragam ngoko, maka orang dianggap memiliki tingkat sosial atau kesopanan yang rendah. Dengan adanya perbedaan tingkat tuturan maka hal ini dapat

\footnotetext{
${ }^{1}$ Sudaryanto. Pemanfaatan Potensi Bahasa. (Yogyakarta: Kanisius, 1989), 88.

2 Siti Mulyani. "Optimalisasi Pembelajaran Bahasa Jawa sebagai Proses Pembentukan Jati Diri” dalam Mulyana (ed). Bahasa dan Sastra Daerah Dalam Kerangka Budaya. (Yogyakarta: Tiara Wacana, 2008), 236.

${ }^{3}$ Siti Mulyani. “Optimalisasi Pembelajaran Bahasa Jawa sebagai Proses Pembentukan Jati Diri” dalam Mulyana (ed). Bahasa dan Sastra Daerah Dalam Kerangka Budaya. (Yogyakarta: Tiara Wacana, 2008), 236
}

616 | Naturalistic: Jurnal Kajian Penelitan dan Pendidikan dan Pembelajaran Vol.4, No.2b (April 2020): 615-620 mencerminkan tingkat kesopanan yang dimiliki antara penutur dan lawan tutur.

Penelitian ini bertujuan untuk mengetahui penguasaan tingkat tutur bahasa Jawa di lingkungan mahasiswa program studi Pendidikan Guru Madrasah Ibtidaiyah di Institut Agama Islam Sunan Giri Ponorogo yang diklasifikasikan dalam dua tingkat tutur yaitu ngoko dan krama. Sedangkan Metode yang digunakan dalam penelitian yaitu deskriptif kualitatif dengan subjek penelitian adalah mahasiswa program studi PGMI di Insuri Ponorogo yang dibagi menjadi 3 kelompok.

\section{B. HASIL DAN PEMBAHASAN}

Bahasa Jawa merupakan bahasa yang mengenal adanya tingkat tutur atau (speech level) atau undha usuk atau unggah-ungguhing basa. ${ }^{4}$ Tingkat tutur Bahasa Jawa kental hubungannya dengan pemakaian bahasa, yang dikelompokkan dalam tingkat ngoko dan krama. Bentuk hirarkis dapat dikatakan juga sebagai undha usuk. Kata hierarkis sendiri dapat diartikan sebagai urutan tingkatan dari atas ke bawah atau sebaliknya. Sehingga bentuk hierarkis bahasa Jawa adalah urutan tingkatan bahasa Jawa dari atas ke bawah atau sebaliknya. Dalam pemakaian bahasa Jawa sebagai media komunikasi, kita tidak dapat melepaskannya dari pemakaian unggahungguhnya. Bahkan dapat dikatakan bahwa esensi nilai kesantunan Bahasa Jawa terletak pada pemahaman penggunaan unggah-ungguh oleh penuturnya. Sehingga ketika seorang penutur menggunakan bahasa Jawa dengan unggahungguh yang tepat maka dipastikan dalam tindakannya ia mempertimbangkan faktor-faktor yang harus dipenuhi.

Data penelitian yang berupa hasil dari kuesioner adalah berupa latar belakang pengguna bahasa (responden) dan kemampuan bahasa responden dalam bahasa Jawa Ngoko dan Krama,. Data kemampuan berbahasa Jawa Ngoko dan Krama dinilai dengan skor salah dan benar. Terdapat 100 kosakata dalam Bahasa Indonesia yang harus diartikan ke dalam bahasa Jawa Ngoko

4 Setiyadi, Dwi Bambang Putut."Pembelajaran Bahasa dan Sastra Jawa dalam Kerangka Budaya sebagai Bagian dari Upaya Pelestarian Kebudayaan dan Bahasa Jawa" dalam Mulyana (ed). Bahasa dan Sastra Daerah Dalam Kerangka Budaya. (Yogyakarta: Tiara Wacana, 2008), 64. 
dan Krama, jika benar mendapat skor 1, jika salah mendapat skor 0. Kebenaran kosakata yang diartikan didasarkan pada Kamus Lengkap Bahasa Jawa $^{5}$ dan Kamus Basa Jawa ${ }^{6}$. Berikut paparan hasil penelitian mengenai bentuk hierarki bahasa Jawa yang masih bertahan pada mahasiswa PGMI Insuri Ponorogo.

\footnotetext{
5 Sudarmanto. Kamus Lengkap Bahasa Jawa.
} 
Tabel 1. Skor Hasil Kemampuan Kosakata Ngoko

\begin{tabular}{|c|c|c|c|}
\hline \multirow{2}{*}{ SKOR KEMAMPUAN 100 KOSAKATA NGOKO } \\
\hline NO & \multicolumn{3}{|c|}{ KELOMPOK } \\
\cline { 2 - 4 } URUT & $\mathbf{1}$ & $\mathbf{2}$ & $\mathbf{3}$ \\
\hline 1 & 79 & 80 & 89 \\
\hline 2 & 83 & 50 & 90 \\
\hline 3 & 76 & 83 & 80 \\
\hline 4 & 85 & 83 & 88 \\
\hline 5 & 80 & 79 & 87 \\
\hline 6 & 79 & 79 & 84 \\
\hline 7 & 83 & 76 & 84 \\
\hline 8 & 82 & 75 & 86 \\
\hline 9 & 82 & 81 & 89 \\
\hline 10 & 82 & 77 & 92 \\
\hline 11 & 85 & 80 & 82 \\
\hline 12 & 85 & 84 & 86 \\
\hline 13 & 88 & 84 & 92 \\
\hline 14 & 75 & & 85 \\
\hline 15 & 80 & & 86 \\
\hline 16 & 83 & & 87 \\
\hline 17 & 75 & & 86 \\
\hline 18 & 82 & & \\
\hline 19 & 78 & & 81 \\
\hline
\end{tabular}

Berdasarkan tabel tersebut, dapat diketahui hasil kemampuan berbahasa Jawa Ngoko dari semua responden di setiap semesternya. Hasil kemampuan di Kelompok 1, dari 19 responden, skor tertinggi adalah 88 dan skor terendah adalah 75 sebanyak 2 responden. Di kelompok 2, terdapat 13 responden dengan skor tertinggi 84 sebanyak 2 responden dan skor terendah 48. Untuk kelompok 3 terdapat 19 responden dengan hasil skor tertinggi 92 sebanyak 2 responden dan skor terendah 80. Terdapat perbedaan kemampuan berbahasa Jawa Ngoko di setiap semesternya. Skor tertinggi diraih oleh responden kelompok 3 yaitu 92 atau hanya salah 8 kosakata dalam bahasa Ngoko. Untuk responden di kelompok 2 meraih skor tertinggi 83 , atau 5 skor lebih rendah dari skor tertinggi di kelompok 1.

Tabel 2. Skor Hasil Kemampuan Kosakata Krama SKOR KEMAMPUAN 100 KOSAKATA KRAMA

\begin{tabular}{|l|c|c|c|}
\hline \multirow{2}{*}{ NO URUT } & \multicolumn{3}{|c|}{ KELOMPOK } \\
\cline { 2 - 4 } & $\mathbf{1}$ & $\mathbf{2}$ & $\mathbf{3}$ \\
\hline
\end{tabular}

\begin{tabular}{|c|c|c|c|}
\hline \multicolumn{3}{|c|}{ SKOR KEMAMPUAN 100 KOSAKATA } \\
\multicolumn{3}{|c|}{ KRAMA } \\
\hline \multirow{2}{*}{ NO URUT } & $\mathbf{1}$ & $\mathbf{2}$ & $\mathbf{3}$ \\
\hline 1 & 15 & 22 & 29 \\
\hline 2 & 23 & 0 & 32 \\
\hline 3 & 16 & 37 & 28 \\
\hline 4 & 31 & 27 & 22 \\
\hline 5 & 11 & 31 & 30 \\
\hline 6 & 29 & 5 & 30 \\
\hline 7 & 23 & 0 & 30 \\
\hline 8 & 14 & 27 & 7 \\
\hline 9 & 27 & 25 & 22 \\
\hline 10 & 24 & 20 & 18 \\
\hline 11 & 16 & 7 & 34 \\
\hline 12 & 29 & 44 & 4 \\
\hline 13 & 31 & 38 & 0 \\
\hline 14 & 40 & & 0 \\
\hline 15 & 26 & & 35 \\
\hline 16 & 25 & & 32 \\
\hline 17 & 20 & & 31 \\
\hline 18 & 26 & & 23 \\
\hline 19 & 28 & & 26 \\
\hline
\end{tabular}


Berdasarkan tabel tersebut, dapat diketahui hasil kemampuan berbahasa Jawa Krama dari semua responden di setiap semesternya. Hasil kemampuan di kelompok 1, dari 19 responden, skor tertinggi adalah 40 dan skor terendah adalah 11 sebanyak 2 responden. Di kelompok 2, terdapat 13 responden dengan skor tertinggi 44 dan skor terendah 0 sebanyak 2 responden. Untuk kelompok 3 terdapat 19 responden dengan hasil skor tertinggi 35 sebanyak dan skor terendah 0 sebanyak 2 responden. Berdasarkan hasil tersebut, diketahui bahwa responden di kelompok 2 meraih skor tertinggi untuk kemampuan berbahasa Jawa Krama yaitu 44. Hal ini berbeda dengan hasil kemampuan berbahasa Jawa Ngoko, skor tertinggi di kemampuan berbahasa Jawa Ngoko adalah responden di kelompok 3 dan terendah di kelompok 2. .

\section{Latar Belakang Pengguna Bahasa}

Berdasarkan hasil kuesioner mengenai latar belakang pengguna bahasa responden kelompok 1, satu responden, yaitu 1.16 mengatakan jika bahasa yang pertama kali dikuasainya atau bahasa ibunya adalah Bahasa Indonesia, sedangkan 18 responden lainnya mengatakan jika bahasa ibu mereka adalah bahasa Jawa. Responden 1.16, memiliki nilai penguasaan kosakata Bahasa Jawa Ngoko 83 dan Jawa Krama 26. Jadi dapat dikatakan, meskipun bahasa perta yang dikuasainya adalah Bahasa Indonesia, bukan bahasa Jawa, tetapi kemampuannya dalam berbahasa Jawa Ngoko adalah baik. Untuk bahasa yang dikuasai selain bahasa ibu dan bahasa Indonesia, 10 responden mengatakan menguasai bahasa asing, berupa bahasa Arab dan bahasa Inggris. Suku bangsa ayah dan ibu responden semuanya dalam Jawa, dan bahasa pertama mereka juga bahasa Jawa, sehingga dapat dikatakan tidak ada pengaruh kedaerahan lain pada bahasa yang dikuasai oleh responden.

Berdasarkan hasil kuesioner mengenai latar belakang pengguna bahasa responden kelompok 2 , seluruh responden yang berjumlah 13 orang mengatakan jika bahasa pertama mereka adalah bahasa Jawa. Untuk bahasa yang dikuasai selain bahasa ibu dan bahasa Indonesia, 9 responden mengatakan menguasai bahasa asing, berupa bahasa Arab dan bahasa Inggris. Suku bangsa ayah dan ibu responden semuanya adalah Jawa, dan bahasa pertama mereka juga bahasa Jawa, sehingga dapat dikatakan tidak ada pengaruh kedaerahan lain pada bahasa yang dikuasai oleh responden.

Berdasarkan hasil kuesioner mengenai latar belakang pengguna bahasa responden kelompok 3, satu responden, 3.4 mengatakan jika bahasa yang pertama kali dikuasainya atau bahasa ibunya adalah Bahasa Indonesia, sedangkan 18 responden lainnya mengatakan jika bahasa ibu mereka adalah bahasa Jawa. Responden 3.4, memiliki nilai penguasaan kosakata Bahasa Jawa Ngoko 88 dan Jawa Krama 22. Jadi dapat dikatakan, meskipun bahasa perta yang dikuasainya adalah Bahasa Indonesia, bukan bahasa Jawa, tetapi kemampuannya dalam berbahasa Jawa Ngoko adalah baik, meskipun kemampuan dalam kosakata bahasa Jawa Krama kurang baik. Untuk bahasa yang dikuasai selain bahasa ibu dan bahasa Indonesia, 11 responden mengatakan menguasai bahasa asing, berupa bahasa Arab dan bahasa Inggris. Suku bangsa ayah dan ibu responden semuanya adalah Jawa, dan bahasa pertama mereka juga bahasa Jawa, sehingga dapat dikatakan tidak ada pengaruh kedaerahan lain pada bahasa yang dikuasai oleh responden.

\section{Tingkat Tutur Bahasa Jawa Mahasiswa}

Tingkat Tutur yang kemudian digunakan sebagai patokan dalam penelitian ini memunculkan hasil bahwa dari semua hasil kemampuan responden, bentuk hierarki yang masih bertahan adalah bahasa Jawa ragam Ngoko. Hal ini ditunjukkan dari hasil kemampuan responden dalam mengartikan 100 kosakata ke dalam bahasa Jawa ngoko dan Jawa Krama, yang menunjukkan bahwa semua hasil kemampuan responden dalam berbahasa Jawa ragam Krama dibawah 50\%, atau di bawah 50 kosakata. Bahkan ada 4 responden yang mendapatkan nilai 0 dalam kemampuannya berbahasa Jawa ragam Krama.

Keadaan ini menunjukkan jika dalam kehidupan berbahasa, responden memang lebih memilih bahasa Jawa ragam Ngoko daripada ragam Krama sehingga kemampuan mereka dalam menggunakan kosakata dalam ragam Krama sangat kurang yang nantinya akan membuat tingkatan/hierarki bahasa iki lama kelamaan akan bergeser dan hilang. Belum lagi dengan kemampuan responden yang juga menguasai bahasa di luar bahasa Jawa, selain bahasa Indonesia, yang berupa bahasa asing, yaitu Arab dan Inggris. adanya pengaruh dari kemampuan responden dalam menguasai bahasa lain, akan 
mempengaruhi kemampuan mereka dalam berbahasa Jawa, khususnya ragam Krama yang sudah mulai terkikis.

Faktor lain yang mempengaruhi bentuk hierarki yang bertahan adalah tidak didukungnya penggunaan bahasa Jawa Krama dalam komunikasi sehari-hari mahasiswa di lingkungan pendidikan. Responden yang merupakan mahasiswa dituntut menggunakan bahasa Indonesia sebagai bahasa pengantar, bahasa Inggris dan bahasa Arab dalam beberapa mata kuliah, membuat responden memilih menggunakan bahasa tersebut dalam komunikasinya. Penggunaan bahasa Jawa ragam Krama yang mulai terbatas pada kalangan tertentu juga membuat upaya pemertahanannya semakin sulit. Responden baru akan menggunakan bahasa Jawa, baik ragam ngoko maupun krama, pada komunikasi non formal.

Adanya mata kuliah bahasa Jawa pada program studi PGMI Insuri selain sebagai mata kuliah wajib, juga diharapkan mendapatkan dampak positif dengan bertahannya kemampuan mahasiswa dalam berbahasa Jawa. Mata kuliah bahasa Jawa yang diberikan dalam 3 semester, diharapkan mampu membuat responden tidak melupakan bahasa Jawa sebagai bahasa pertamanya. Selain itu, diharapkan kemampuan mahasiswa dalam menggunakan bahasa Jawa baik lisan maupun tulisan, mengalami peningkatan dan jangan sampai bahasa Jawa mengalami pergeseran hingga mengalami kepunahan.

\section{SIMPULAN}

Hasil penelitian ini menunjukkan kemampuan berbahasa Jawa ngoko di kelompok 1, dari 19 responden, skor tertinggi adalah 88 dan skor terendah adalah 75 sebanyak 2 responden. Di kelompok 2, terdapat 13 responden dengan skor tertinggi 84 sebanyak 2 responden dan skor terendah 48. Untuk kelompok 3 terdapat 19 responden dengan hasil skor tertinggi 92 sebanyak 2 responden dan skor terendah 80. Hasil kemampuan berbahasa Jawa Krama di kelompok 1, dari 19 responden, skor tertinggi adalah 40 dan skor terendah adalah 11 sebanyak 2 responden. Di kelompok 2, terdapat 13 responden dengan skor tertinggi 44 dan skor terendah 0 sebanyak 2 responden. Untuk kelompok 3 terdapat 19 responden dengan hasil skor tertinggi 35 sebanyak dan skor terendah 0 sebanyak 2 responden. Jelas terlihat perbedaan yang signifikan mengenai penguasaan tingkat tutur Bahasa Jawa di lingkungan mahasiswa prodi PGMI di INSURI Ponorogo yang lebih menguasai bahasa Jawa ngoko dibanding bahasa Jawa Krama.

\section{DAFTAR PUSTAKA}

Mulyani, Siti. "Optimalisasi Pembelajaran Bahasa Jawa sebagai Proses Pembentukan Jati Diri" dalam Mulyana (ed). Bahasa dan Sastra Daerah Dalam Kerangka Budaya. Yogyakarta: Tiara Wacana, 2008.

Setiyadi, Dwi Bambang Putut."Pembelajaran Bahasa dan Sastra Jawa dalam Kerangka Budaya sebagai Bagian dari Upaya Pelestarian Kebudayaan dan Bahasa Jawa" dalam Mulyana (ed). Bahasa dan Sastra Daerah Dalam Kerangka Budaya. Yogyakarta: Tiara Wacana, 2008.

Sudarmanto. Kamus Lengkap Bahasa Jawa.. Semarang: Widya Karya, 2016.

Sudaryanto. Pemanfaatan Potensi Bahasa. Yogyakarta: Kanisius, 1989.

Windarti, Nursam. Kamus Bahasa Jawa. Yogyakarta:Pustaka Widyatama, 2012.

Wiryanti, Sri. "Pengajaran Unggah-Ungguh Bahasa Jawa sebagai Penanaman Nilai Kesantunan dalam Berbahasa”. Makalah Kongres Bahasa Jawa IV. Semarang, 2006. 